UDC 340.13

\title{
Immediate Steps of Judicial Reform in Ukraine
}

\author{
Aleksandr B. Kapustin, lawyer, \\ Founder of "The European Union of Christian Attorneys", Odessa, Ukraine
}

\begin{abstract}
The United State Agency for International Development (USAID), the Center of the European researches, the International Monetary Fund (IMF), OSCE, the Council of Europe, GRECO carried out the Ukrainian reforms project and other projects together with the Ukrainian authorities, allocated the huge amounts of money to Ukraine for carrying out reforms in the field of the right. Dull haste of the previous power led to the fact that for universal dismissal of judges and enrollment for work of new personnel in courts: many courts operating in Ukraine, including the Supreme Court of Ukraine were liquidated. As now, it is visible from the decision of the Constitutional Court of Ukraine that the reforms were undertaken contrary to provisions of the Constitution of Ukraine. Therefore, with the Decision of the Constitutional Court of Ukraine N 2-p/2020 dated 18.02.2020 we state new and rather next collision of reforming of the right in Ukraine. All this is absolutely and certainly reflected in the constitutional guarantees of independence of judges, affects both prestige and trust of citizens to judicial authority and morale of judges. Monetary grants of the international donors are once again spent by the authorities of Ukraine not reasonably and not effectively. In inferior courts, some citizens dare to pour paint in buildings of the courts over judges, to spit the Themis's representatives. Periodically the power of Ukraine tries to review (reduce) the monetary reward to judges. As we have noticed it above, all this affects both prestige of employees of the court, and trust of citizens to Themis. The personnel hunger in courts of Ukraine is catastrophic; courts due to the lack of judges are systematically closed. The reformed procedural legislation provides the introduction of the institute of jurymen; however, citizens do not want to be directly involved in sentences of justice and everywhere personnel hunger in the matter is seen. The immediate measures proposed in this work will lead to quick and effective overcoming the crisis in judicial reform.
\end{abstract}

Keywords: Judicial reform, the judicial system, justice, independence of judges, guarantees of legal proceedings.

\section{Introduction}

The legislation and practice of its application inevitably absorb in themselves the previous experience of the human civilization. In the state and legal sphere - it is, first of all, those its stages when democratic principles of the social system and such progressive political and legal ideas as supremacy of law, the constitutional state, separation of the authorities, the priority of the rights and freedoms of the person over other social values began to get into public consciousness and practice gradually. At the same time, it is pertinent to remember the known sayings: "New is well forgotten old" and "History teaches us to the fact that it teaches us to nothing". The last in its pointed polemic form emphasizes inability or unwillingness of some statesmen and scientists-lawyers to wholly make use of historical experience of state and legal construction, including domestic. There can be the question: about what loan of experience in the state and legal sphere can there be a speech concerning the absolutist Russian Empire, in which the most of present Ukraine or the totalitarian Soviet state had been. But the ambiguously negative answer to this question 
would be wrong and in essence anti-historical. Therefore, first, it is always possible to find something positive in complex systems of legal regulation and to use it in modern conditions. Second, it is possible to avoid mistakes which had been made in due time by our predecessors. [1, pp. 309-310].

The judicial reform is the set of interconnected, system, normative fixed at the nationwide level (by codification included) changes in the area of the judicial system and the legal proceedings undertaken for the achievement of maximum efficiency of functioning of the judicial system and performed during the historically limited period.

The declaration on the state sovereignty of Ukraine adopted by the Supreme Council of the Ukrainian SSR on July 16, 1990, proclaimed the state sovereignty of Ukraine. The declaration proclaimed: "All citizens are equal in the eyes of the law, irrespective of the origin, the social and property status, the racial and national identity, sex, education, political views, religious beliefs, the sort and character of occupations". On August 24, 1991, the Supreme Council of the Ukrainian SSR adopted the Act of Declaration of Independence of Ukraine and adopted the Resolution "About Declaration of Independence of Ukraine" which announced Ukraine as the independent democratic state. From the moment of formation of modern Ukraine, that is for nearly three decades, in Ukraine reforms are undertaken. A legislator of Ukraine continuously reforms judicial authority.

At the heart of judicial and legal reform in Ukraine accepted by the Supreme Council of Ukraine on April 28, 1992, it was indicated that need of judicial and legal reform is caused by the fact that courts endure the deep crisis caused by many factors which negatively influence their activity. The judicial reform undertaken in Ukraine was intended to make the number of cardinal changes, to accept precepts of the law which in the set shall change the judicial system of Ukraine, that is the system of the judicial organization and the order of permission of legal cases. The crucial elements of the reform are reorganization of courts and reduction of the staff of judges; updating and clarification of the judicial body - the qualified estimation of the effective judges; and also competitive selection: both candidates for the judgeship, and effective judges at their personnel movement (change of court or specialization of the judge); independence of judicial management: the public authority to which competence including also forming of the judicial body and execution of authority punishments - the Supreme Council of Justice are referred is created; optimization of legal proceedings: electronic legal proceedings, remote legal proceedings, increase in court fee, lawyer monopoly for representation in courts, introduction of the concept of "standard or model affairs", modification of the existing procedural codes of Ukraine. [2].

So, as we have established above, for all history of the existence of modern Ukraine, a legislator of Ukraine undertakes in the country infinite reform in the field of justice. At the same time, reforms in the field of the judicial system, legal professions that is - not specialists in that area are engaged in the legal reforms. Many projects of schools of sciences 
of jurisprudence of Ukraine and remained unconsidered by the Supreme Council of Ukraine as in the most cases all next "large-scale" reforms are undertaken spontaneously - to please to the next won political force and have rather populist character, without setting as the purpose improvement of quality of life of the Ukrainian people, and in this case, their right to fair trial and protection of the civil and constitutional rights.

The Constitutional Court of Ukraine notes that renaming of the authority fixed in the Constitution of Ukraine - the Supreme Court of Ukraine - may not happen without transfer of judges of the Supreme Court of Ukraine into positions of judges of the Supreme Court as there are no distinctions between the legal position of a judge of the Supreme Court of Ukraine and a judge of the Supreme Court, and withdrawal of the word "Ukraine" - the own state - from the verbal structure "The Supreme Court of Ukraine" may not be the basis for release of all judges of the Supreme Court of Ukraine or their transfer to another court, especially a lower court. The Constitutional Court concluded that the judges of the Supreme Court of Ukraine should continue to perform the powers as the judges of the Supreme Court. Therefore, the actual differentiation of the judges of the Supreme Court of Ukraine and the Supreme Court does not accord with the principle of the irremovability of judges; it is the compound constitutional guarantee of the independence of judges - the Decision of the Constitutional Court of Ukraine N 2-p/2020 dated 18.02.2020. [3].

On February 18, the Constitutional Court adjudged liquidation of the Supreme Court of Ukraine during the judicial reform of 2016 as unconstitutional. By its decision of 18.02.2020, the Constitutional Court adjudged provisions of such clauses of Section XII "Final and Transitional Provisions" of the Law "On the Judicial System and the Status of Judges": - 7 - about liquidation of the Supreme Court of Ukraine; - 14 - concerning competition to the position of the judges of the Supreme Court; - 25 - about the right to monthly perpetual monetary pay - to not correspond the Constitution. Thus, the Constitutional Court of Ukraine concluded that the judges of the Supreme Court of Ukraine should continue to perform the powers as the judges of the Supreme Court. The relevant provisions of the Law "On the Judicial System and the Status of Judges" become not applicable from the date of adoption of this decision by the Constitutional Court of Ukraine. However, the Constitutional Court in the decision did not call into question competition on screening of the judges in the new Supreme Court. Besides that, the Constitutional Court of Ukraine did not adjudge creation of the new Supreme Court (that is the clauses of the Law based on which, it was created) as unconstitutional.

As it is stated above, reforms in the field of the right in Ukraine did not yield a positive result, which citizens of Ukraine had expected. We offer immediate emergency steps, which will lead to recovery of prestige of the occupation of judge, including to the material guarantee of the salary of judges as the part of the legislative package of independence of judges, and in turn will result in the efficiency of the judicial system, we suggest to make the following changes to the legislation of Ukraine: 
1. To make the following changes to paragraph 3 of article 135 of the Law of Ukraine "On the Judicial System and the Status of Judges": The basic amount of the official pay rate of a judge is:

1) judges of local court - 50 (instead of specified now 30) living wages for ablebodied persons, the amount of which was established for January 1 of a calendar year;

2) justices of appeal, judges of the supreme specialized court - 60 (instead of specified now 50) living wages for able-bodied persons, the amount of which was established for January 1 of a calendar year;

3) judges of the Supreme Court - 70 (instead of specified now 55) living wages for able-bodied persons, the amount of which was established for January 1 of a calendar year.

To make the following changes to paragraph 7 of article 135 of the Law of Ukraine "On the Judicial System and the Status of Judges": Monthly surcharge for scientific degree of Candidate (Doctor of Philosophy) or Doctor of Sciences with the corresponding specialty at a rate of respectively 20 and 25 (instead of specified now 15 and 20) per cent of the official pay rate of the judge of the relevant court is paid to the judges.

Monthly surcharge for the state awards of Ukraine - the honorary title: The honoured lawyer of Ukraine, and (or) the Honored academic and technical figure of Ukraine (now it is not paid) of 10 per cent of the official pay rate of the judge of the relevant court is paid to the judges for each award.

2. To state article 376 of the Criminal Code of Ukraine in the following version:

1). Intervention in any form in the activity of the judge with the purpose to interfere with the accomplishment of service duties by him/her or to achieve pronouncement of an illegal decision is punished by corrective works for a period of from one year up to two years, or arrest for a period of up to six months.

2 ). The same actions, if they interfered prevention of a crime or detention of a person who had made it, or executed by a person with use of the official position, are punished by deprivation of the right to hold certain positions and to be engaged in the certain activity for a period of up to five years and imprisonment for a period of from three to five years.

3. To state article 377 of the Criminal Code of Ukraine in the following version:

1) Threat of murder, violence, destruction or damage of property concerning a judge, a juryman or a juror, and concerning their close relatives in connection with their activity connected with implementation of justice is punished by restriction of freedom for a period of up to three years or imprisonment for a period of from three to five years. 
2) Intentional causing a judge, a juryman or a juror or to their close relatives beating, bodily damages of light or medium severity in connection with their activity connected with implementation of justice is punished by restriction of freedom for a period of up to five years or imprisonment for a period of from five to eight years.

3). Intentional causing heavy bodily damage to a judge, a juryman or a juror or their close relatives in connection with their activity connected with implementation of justice is punished by imprisonment for a period of from eight to fourteen years.

4. To state article 378 of the Criminal Code of Ukraine in the following version:

1). Intentional destruction or damage of the property belonging to a judge, a juryman or a juror or their close relatives in connection with their activity connected with implementation of justice is punished by imprisonment for a period of from five to eight years.

2). The same actions made by arson, explosion or another all-dangerous method, or which entailed death of people or other heavy effects are punished by imprisonment for a period of from eight to fifteen years.

\section{Conclusions:}

Reforms in the field of justice, which are undertaken systematically in Ukraine, have spontaneous character; numerous scientific lawyers are not involved in their development, as the central element the political idea of authorities in power is often brought in the basis of those reforms. The steps specified by us will without delay render essential measures: on recovery of independence of legal proceedings in Ukraine, to efficiency of any further reforms which would be obvious to be carried out the newly elected power of Ukraine, to recovery of trust of citizens to judicial authority of Ukraine, recovery of prestige of the occupation of a judge and respectively to filling a judicial authority by the professional personnel. Moreover, the problem of hunger for the personnel, and the actual absence of wish of citizens of Ukraine to become jurymen would also respectively be solved positively.

\section{References}

1. Yu. E. Polianskii. Use of historical and analytical approach in the course of judicial reform in Ukraine. / Yu. E. Polianskii // Urgent problems of the state and right. - Odessa: "Legal literature", No. 45, 2009. - pp. 309-310.

2. A. B. Kapustin. Judicial reform in Ukraine: Legal collapse and its reasons. / A. B. Kapustin // Constitutional state. - Odessa: "Phoenix", No. 29, 2018.

3. The decision of the Constitutional Court of Ukraine of 18.02.2020 on the case on the constitutional representation of the Supreme Court of Ukraine N 2-p/2020. 
Case N 1-15/2018 (4086/16) [The electronic resource]. - Access mode: http://www.ccu.gov.ua/sites/default/files/docs/2_p_2020.pdf?fbclid=IwAR3a4SjQ htgFfUd_vhUzdeU4c_4Kk-Cv-azXKNgWdxw9ufrDY0vZP1hRE9k2 